\title{
Bionomic data and larval density of Scarabaeidae (Pleurosticti) in sugarcane in the central region of Mato Grosso do Sul, Brazil
}

\author{
Gilmar Vieira Coutinho ${ }^{1}$, Sérgio Roberto Rodrigues ${ }^{1}$, Edna Cristina da Cruz $^{2} \&$ Alfredo Raul Abot ${ }^{1}$
}

\author{
'Universidade Estadual de Mato Grosso do Sul, Rodovia Aquidauana, CERA km 12, 79200-000 Aquidauana-MS, Brasil. \\ gilmarcoutinho@hotmail.com; sergio@uems.br; arabot@uems.br \\ ${ }^{2}$ Companhia Brasileira de Açúcar e Álcool/Unidade de Sidrolândia, Estrada Quebra Coco, km 9, 79170-000 Sidrolândia-MS, Brasil. \\ edna.cruz@cbaa.ind.br
}

\begin{abstract}
Bionomic data and larval density of Scarabaeidae (Pleurosticti) in sugarcane in the central region of Mato Grosso do Sul, Brazil. Phytophagous larvae of Scarabaeidae cause damage to diverse crops. Information on these pests is scarce; therefore, the objective of this study was to determine biological aspects and larval density of species occurring in an area of sugarcane. The studies were developed in Sidrolândia from April 2009 to March 2010. Scarab beetle larvae were collected in sugarcane roots every fifteen days, taken to the laboratory and reared to obtain the adults and determine biological parameters. A total of 2,656 larvae were collected, being 162 Liogenys fuscus, 120 Cyclocephala verticalis, 37 Cyclocephala forsteri, and 2337 Anomonyx sp. In January, 53.65 larvae $\mathrm{m}^{-2}$ were obtained, and the most abundant species was Anomonyx sp, representing $87.99 \%$ of the total larvae collected. From November to March, the greatest densities of Anomonyx were observed in the field. The adults of this species occurred from May to September, and egg laying from September to November. Eggs measured 1.1 x $1.7 \mathrm{~mm}$, and incubation period last 15.4 days. First instar larvae were observed mainly in October; second instar larvae from November to April; and third instar from January to July. Pupae were observed from May to August. The most abundant scarab beetle, Anomonyx sp. in roots of sugarcane presents one generation per year in Sidrolândia, MS.
\end{abstract}

KEYWORDS. Insect biology; Saccharum officinarum; Scarabaeoidea; soil pests.

RESUMO. Dados bionômicos e densidade larval de Scarabaeidae (Pleurosticti) em cultura de cana-de-açúcar na região central de Mato Grosso do Sul, Brasil. Larvas fitófagas de Scarabaeidae causam danos em diversas culturas. Entretanto as informações sobre essas pragas são bastante escassas. Assim, o objetivo deste estudo foi determinar aspectos morfológicos, biológicos e densidade larval de escarabeídeos em área de cana-de-açúcar. Os estudos foram desenvolvidos em Sidrolândia, MS, de abril de 2009 a março de 2010. As larvas presentes nas raízes de cana-de-açúcar foram coletadas quinzenalmente, levadas para o laboratório e criadas até a obtenção de adultos e avaliação de parâmetros biológicos. Foram coletadas 2.656 larvas, sendo 162 de Liogenys fuscus, 120 de Cyclocephala verticalis, 37 de Cyclocephala forsteri e 2337 Anomonyx sp. Em janeiro, foram registradas 53,65 larvas m ${ }^{-2}$, sendo Anomonyx sp. a espécie mais abundante, representando $87,99 \%$ do total. De novembro a março, foram observadas as maiores densidades de Anomonyx no campo. Os adultos foram observados de maio a setembro. A postura ocorreu de setembro a novembro. Os ovos mediram 1,1x 1,7 mm, com período de incubação de 15,4 dias. As larvas de primeiro ínstar foram observadas em outubro, as de segundo ínstar de novembro a abril e as de terceiro de janeiro a julho. As pupas ocorreram de maio a agosto. A espécie de Scarabaeidae mais abundante na cana-de-açúcar é Anomonyx sp., que apresenta uma geração por ano.

PALAVRAS-CHAVE. Biologia de inseto; pragas-de-solo; Saccharum officinarum; Scarabaeoidea.

Phytophagous beetles of the family Scarabaeidae are important pests in various crops. Damage is caused mainly by the larvae that chew on the roots of several gramineae (Poaceae). Sugarcane production is in rapid expansion in the central-west region of Brazil and some scarab species are reported as pests, including Ligyrus sp., Stenocrates spp. and Euetheola humilis (Burmeister, 1847) (Gallo et al. 2002) and Strategus aloeus (L., 1758) (Pereira et al. 2004). Despite the importance of Scarabaeidae as a crop pest, information on the association of this group with sugarcane is scarce in Brazil.

In Mexico, Aragón-García \& Morón (2000) reported the occurrence of Cyclocephala lunulata Burmeister, 1847 and Phyllophaga brevidens (Bates, 1888) associated with sugarcane. Gordon \& Anderson (1981) registered the occurrence of Phyllophaga latifrons (LeConte, 1856), Anomala marginata (F., 1972), Cyclocephala parallela Casey, 1915,
Dyscinetus morator (F., 1798), Ligyrus subtropicus Batchley, 1922 and Euphoria sepulchralis (F., 1801) in sugarcane crops in Florida, USA. In Japan, Arakaki et al. (2004a,b) related Dasylepida ishigakiensis (Niijima \& Kinoshita, 1927) and Anomala albopilosa sakishimana Nomura, 1964 causing damage to the root system of sugarcane plants and Oyafuso et al. (2002) also studied and reported Scarabaeidae species as pests to sugarcane.

In order to control these pests and minimize adverse effects, it is necessary to obtain information of their biological aspects in regions of interest. Therefore, it is initially necessary to identify the species and determine basic biological parameters. Next, population dynamics should be evaluated, considering host plants, control agents and environmental factors responsible for mortality (Aragón-García \& Morón 2000). 
Taking into consideration that areas cultivated with sugarcane are in expansion in Brazil and there is little information on phytophagous Scarabaeidae occurring on this culture, the objective of the present study was to evaluate biological aspects and density of larvae of scarab beetles in sugarcane, in Sidrolândia, in the central region of Mato Grosso do Sul, Brazil.

\section{MATERIAL AND METHODS}

The experiment was conducted in a commercial sugarcane field in the county of Sidrolândia, in the central region of the state of Mato Grosso do Sul, Brazil (20 $47^{\prime} \mathrm{S}$; $55^{\circ} 05^{\prime} \mathrm{W}$; $300 \mathrm{~m}$ in altitude), managed by Companhia Brasileira de Açúcar e Álcool. Two stands were selected, one with an area of 49.90 ha planted with cultivar SP81 3250 (medium maturation cycle and susceptible to nematodes) and the other measuring 41.14 ha and planted with cultivar RB867515 (late maturation cycle). Harvesting was performed in the second half of September for cultivars SP81 3250 and by the end of November of 2009 for cultivar RB867515. The plants were burned and manually cut.

From April 2009 to March 2010, 48 soil samples measuring $25 \times 25 \mathrm{~cm}$ and $30 \mathrm{~cm}$ deep were randomly collected from each stand near the root system, every 15 days (methodology adapted from Silva \& Loeck 1996; Silva \& Costa 1998). Therefore, the 48 samples of each stand represented an area of $3 \mathrm{~m}^{2}$. The soil samples were sieved and the scarab beetle larvae removed and quantified. For identification of the Scarabaeidae complex, the larvae were taken to the Laboratory of Entomology of the Universidade Estadual de Mato Grosso do Sul, in Aquidauana, MS, Brazil and reared individually in $500 \mathrm{~mL}$ plastic recipients containing soil and sugarcane sprouts to obtain the adults (method adapted from Aragón-García \& Morón 2000; Pardo-Locarno et al. 2005).

The rearing recipients were maintained at $26 \pm 2{ }^{\circ} \mathrm{C}$ and inspected twice a week. When the sugarcane sprouts began to wither and dry out they were replaced. The following parameters were evaluated: time of egg incubation, width of the larval cephalic capsule, body width, body length and larval weight (adapted from Rodrigues et al. 2010).

Larvae quantities were grouped in each sampled month and after that they were subjected to analysis of variance. The monthly averages were compared using the Tukey test $(\mathrm{P}<0.05)$.

Some species were identified by comparison with the entomological collection of insects at the State University of Mato Grosso do Sul, in Aquidauana, MS.

\section{RESULTS AND DISCUSSION}

A total of 2,656 larvae, five pupae and four adults were obtained from the soil samples during 12 months of sampling. Four species of phytophagous Scarabaeidae were identified; Liogenys fuscus Blanchard, 1850, Anomonyx sp, Cyclocephala forsteri Endrodi, 1963 and Cyclocephala verticalis Burmeister, 1847.
Scarabaeidae larvae have three larval instars (Rodrigues et al. 2008; Santos \& Avila 2007), and in this experiment the scarab larvae were found during the entire year, with population peaks from November to March and only few specimens from April to October.

Significant differences were observed in larval density, the greatest being in January, with a mean of 53.65 larvae $\mathrm{m}^{-2}$ (Fig. 1). High larval density observed from November to March followed the period of intensive adult activities and reproduction in October and November. According with Rodrigues et al. (2008), Rodrigues et al. (2010) and Santos \& Ávila (2007), the reproduction peak for L. fuscus, C. verticalis and $C$. forsteri is from September to November, resulting in the high larval density observed in the following months.

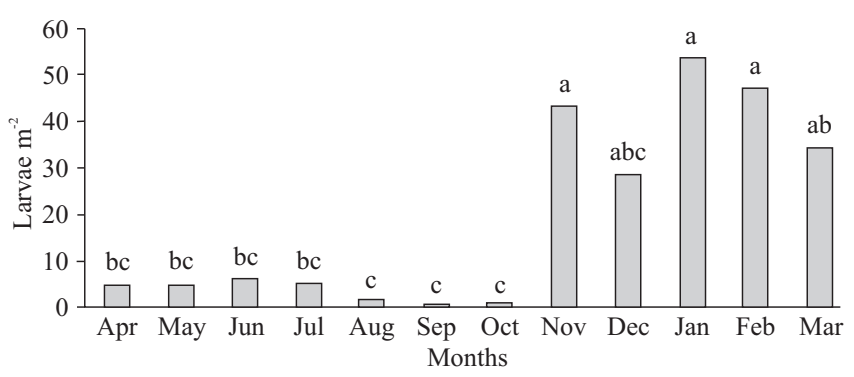

Fig. 1. Mean density of larvae $\mathrm{m}^{-2}$ of phytophagous Scarabaeidae sampled in sugarcane, in Sidrolândia, MS, from April 2009 to March 2010. Means followed by the same letter do not significantly differ by the Tukey test $(\mathrm{P}<0.05)$

The high density of scarab larvae in soybean crops has been reported in the state of Paraná by Oliveira et al. (1997). They observed an average of 20 larvae $\mathrm{m}^{-2}$ during the sowing period. Phyllophaga cuyabana was the species causing the most damage.

In both sugarcane cultivars similar quantities of larvae were sampled, being 1,223 larvae in the SP81 3250 cultivar and 1,433 larvae in the RB867515 cultivar. The larvae dinamyc in the two stands was similar, and the highest average was 86.70 larvae $\mathrm{m}^{-2}$ in the cultivar RB867515 (Fig. 2).

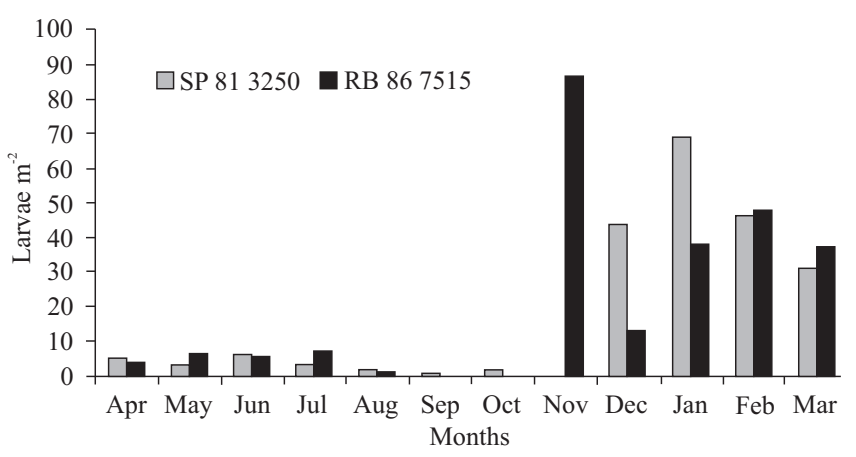

Fig. 2. Mean density of larvae $\mathrm{m}^{-2}$ of phytophagous Scarabaeidae sampled in two sugarcane varieties, in Sidrolândia, MS, from April 2009 to March 2010. 
Based on morphological characteristics, the third instar larvae can be differentiated from the others larval instars. $L$. fuscus presents mean cephalic capsule width of $3.77 \mathrm{~mm}$ (3.3$4.1 \mathrm{~mm}$ ) and body length of $23.44 \mathrm{~mm}$, and the raster possesses two rows of palidia with 3 to 4 large setae (ranging from 2 to 4 setae by pali) (Fig. 3). In C. verticalis the width of the cephalic capsule is $4.25 \mathrm{~mm}(4.0-4.7 \mathrm{~mm})$ and body length is $26.11 \mathrm{~mm}$. The raster presents one row of palidia and two to four bifid pairs of setae (2-4 bifid setae by pali) (Fig. 3).

Larvae of $C$. forsteri has cephalic capsule width of 5.78 $\mathrm{mm}(5.3-6.2 \mathrm{~mm})$ and mean length of $33.23 \mathrm{~mm}$. In the region of the raster various setae are observed, however there is no palidia (Fig. 3). The larvae of Anomonyx sp, present mean cephalic capsule width $3.05 \mathrm{~mm}(2.6-3.8 \mathrm{~mm})$ and body length of $19.53 \mathrm{~mm}$. The raster possesses two rows of palidia with mean of 12 a 13 setae on each (10-14 setae by pali) (Fig. 3).

Some biological and behavioral aspects of each species were observed, as follows (Table I).

Liogenys fuscus. From April to September, 116 larvae of L. fuscus were collected, from these 27 reached the pupal stage and 13 adults emerged in the laboratory. The larvae collected during this period were in the third instar, and $94.4 \%$ were in pre-pupa stage. These pre-pupae presented white bodies and remained for an average of $92.4 \pm 17.0$ days in this stage $(n=9)$ (Table I).

In October and November no larvae were collected in the field. From December to March 46 larvae were sampled, usually in low density. In July the population increased and a mean of 6 larvae $\mathrm{m}^{-2}$ were recorded (Fig. 4).

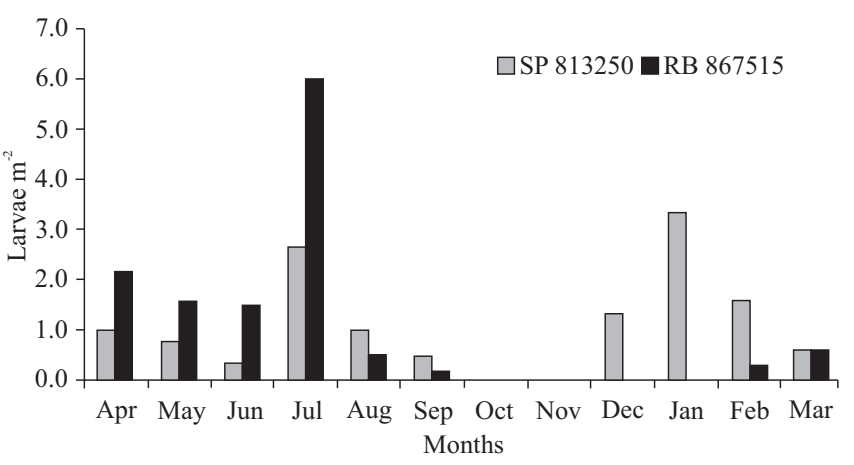

Fig. 4. Mean density of larvae $\mathrm{m}^{-2}$ of Liogenys fuscus sampled in two sugarcane varieties, in Sidrolândia, MS, from April 2009 to March 2010.
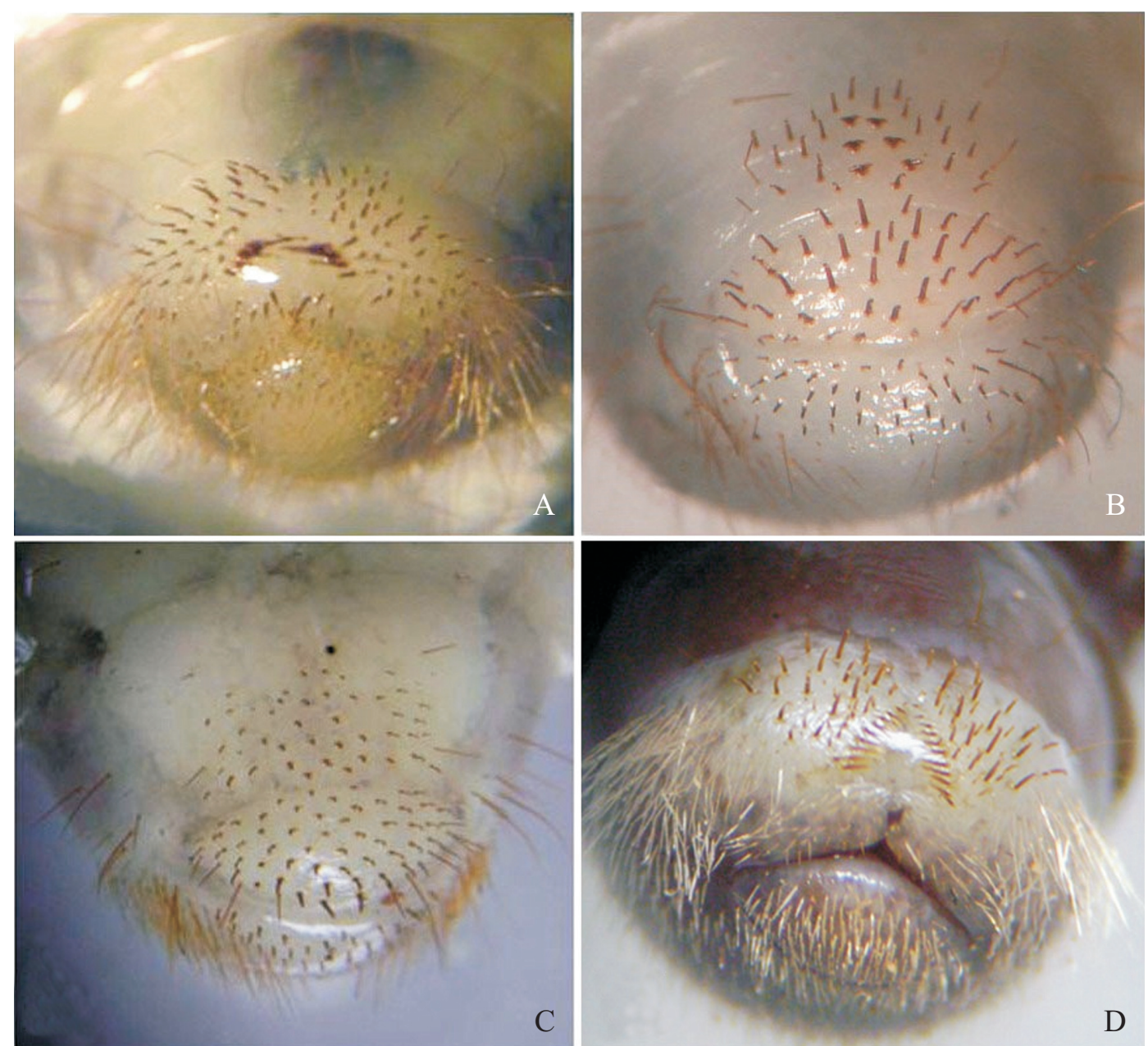

Fig. 3. Rasters of Liogenys fuscus (A), Cyclocephala verticalis (B), Cyclocephala forsteri (C) and Anomonyx sp. (D). 
Table I. Biometrics and biological data of Anomonyx sp., Liogenys fuscus, Cyclocephala forsteri and C. verticalis sampled in sugarcane, in Sidrolândia, MS, from April 2009 to March 2010.

\begin{tabular}{|c|c|c|c|c|c|}
\hline Species & Phase & Duration (days) & Cephalic capsule (mm) & Length $(\mathrm{mm})$ & Weight (mg) \\
\hline \multirow[t]{6}{*}{ Anomonyx sp. } & Egg & 15.40 & - & 1.70 & - \\
\hline & $1^{\text {st }}$ instar & 50.00 & $1.31(1.0-1.6)$ & 9.32 & $15.53(2.4-20.2)$ \\
\hline & $2^{\text {nd }}$ instar & 73.00 & $2.09(1.7-2.5)$ & 14.10 & $50.31(24.3-97.0)$ \\
\hline & $3^{\text {rd }}$ instar & 167.00 & $3.05(2.6-3.8)$ & 19.53 & 179.54 (113.3-319.7) \\
\hline & Pre-pupa & 15.00 & - & - & - \\
\hline & Pupa & 28.80 & - & - & - \\
\hline \multirow[t]{3}{*}{ Liogenys fuscus } & $2^{\text {nd }}$ instar & - & 2.30 & - & - \\
\hline & Pre-pupa & 92.40 & $3.77(3.3-4.1)$ & 23.44 & $402.20(301,3-542.6)$ \\
\hline & Pupa & 25.30 & & & \\
\hline \multirow[t]{7}{*}{ Cyclocephala forsteri } & Egg & 17.00 & - & - & - \\
\hline & $1^{\text {st }}$ instar & 31.00 & 2.50 & - & - \\
\hline & $2^{\text {nd }}$ instar & 53.00 & 3.80 & - & - \\
\hline & $3^{\text {rd }}$ instar & 70.00 & $5.78(5.3-6.2)$ & 33.23 & $1378.41(993.3-1662.0)$ \\
\hline & Pre-pupa & 65.50 & - & - & - \\
\hline & Pupa & 20.50 & - & - & - \\
\hline & Adult & 23.00 & - & - & - \\
\hline \multirow[t]{5}{*}{ Cyclocephala verticalis } & $1^{\text {st }}$ instar & - & $1.62(1.5-1.7)$ & - & - \\
\hline & $2^{\text {nd }}$ instar & - & $2.66(2.2-3.1)$ & - & - \\
\hline & $3^{\text {rd }}$ instar & - & $4.25(4.0-4.7)$ & 26.11 & 535.57 (432.4-840.7) \\
\hline & Pré-pupa & 32.76 & - & - & - \\
\hline & Pupa & 17.38 & - & - & - \\
\hline
\end{tabular}

Third larval instar presents cephalic capsule width of $3.77 \mathrm{~mm}(\mathrm{n}=100)$, body length of $23.44 \mathrm{~mm}(\mathrm{n}=73)$ and weight of $402.20 \mathrm{mg}(\mathrm{n}=58)$. Pupae of L. fuscus were observed from August to September and pupal stage duration of $25.53 \pm 9.3$ days $(n=13)$ (Table I). Adults were found from August to October. Larvae of $L$. fuscus presented simillar behavior in pasture areas, according to Rodrigues et al. (2008). Its behavior is also similar to that of Liogenys suturalis (Blanchard, 1851) in crop areas (Santos \& Ávila 2009). Larvae in the second instar were obtained from December to February and have cephalic capsule width of $2.3 \mathrm{~mm}(\mathrm{n}=14)$.

Larvae of $L$. fuscus have been reported feeding on the roots of Brachiaria decumbens (Rodrigues et al. 2008) and adults occurring in areas of no-till soybeans (Costa et al. 2009). It has been verified that this species is very polyphagous, feeding on different crops, including sugarcane.

Anomonyx sp. A total of 2,337 larvae of Anomonyx sp were sampled; 21 reached pupal stage and 7 adults emerged in the laboratory. Many larvae did not complete the biological cycle because they were injured during sampling and others probably did not adapt to the laboratory conditions. The quantity of Anomonyx larvae collected represented $87.99 \%$ of all larvae sampled in this sugarcane area.

From April to July, small quantities of larvae in the third instar were collected in the field, and from June to October the stand with cultivar RB867515 was not sampled (Fig. 5). From November 2009 to March 2010 the greatest densities of Anomonyx sp, larvae were sampled in the areas of sugar- cane. In November, the stand of cultivar RB 867515 a density of 80.3 larvae $\mathrm{m}^{-2}$ was recorded (Fig. 5). High densities of larvae during November coincided with the rainy season in the region of Sidrolândia, and resulted from the period of reproduction and oviposition in the previous two months. The populations of larvae remained at high densities until March, after that they decreased and kept low until October, probably due to the normal life cycle of species of Anomonyx and high mortality due to the action of predators or pathogens.

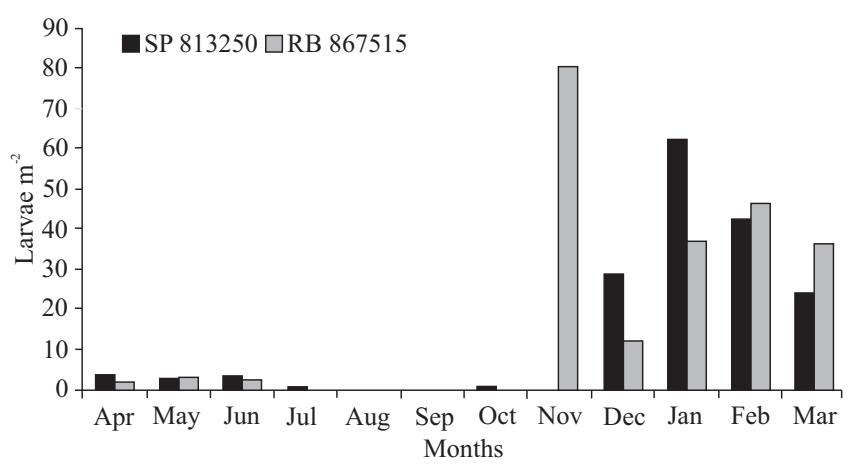

Fig. 5. Mean density of larvae $\mathrm{m}^{-2}$ of Anomonyx sp. sampled in two sugarcane varieties, in Sidrolândia, MS, from April 2009 to March 2010.

On this subject Rodrigues et al. (2011) also reported a decrease in the larval density of Scarabaeidae in crop rota- 
tion systems, being related to natural mortality, pathogens and predators action as causing this population decline.

Only one larva was observed alive in vials where 3 to 5 larvae were reared together, indicating cannibalism. Even in the field, this behavior may be observed when there are many larvae together, what may represent another factor of larval mortality.

Eggs of Anomonyx were observed in the field from September to November (Fig. 6). The eggs are deposited in groups of 3 to $5(n=5)$ or isolated in the soil $(n=40)$. In the laboratory it was recorded a mean of 38 eggs/female, and the incubation period lasted 15.4 days $(\mathrm{n}=20)$. Each eggs were oval and measured $1.1 \times 1.7 \mathrm{~mm}$ in average $(\mathrm{n}=15)$ (Table I).

First instar larvae of Anomonyx were first collected in October at low densities in the stand with SP81 3250. In the cultivar RB867515, first instar larvae were observed at high densities until November. Second instar larvae were observed from November to until April. Third instar larvae occurred from January to March (Fig. 6).

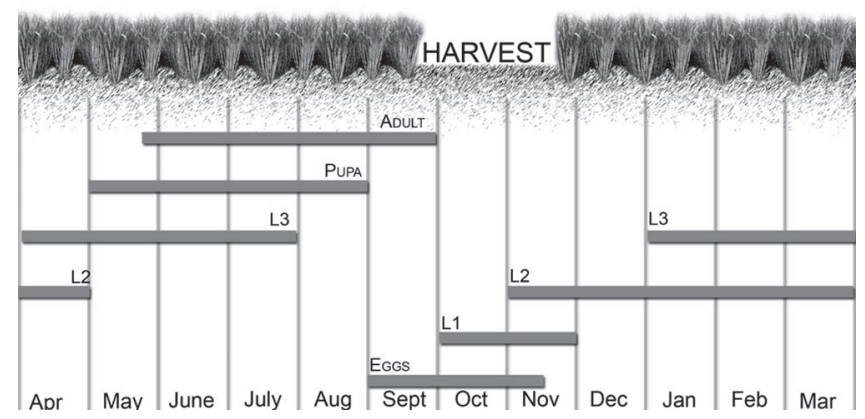

Fig. 6. Development phases of Anomonyx sp. in sugarcane in Sidrolândia, MS, from April 2009 to March 2010.

The cephalic capsule of first instar larvae presented a width of $1.31 \mathrm{~mm}(\mathrm{n}=24)$, body width of $9.32 \mathrm{~mm}(\mathrm{n}=13)$, weight of $15.53 \mathrm{mg}(\mathrm{n}=6)$ and duration of 50 days $(n=6)$. Those in the second instar presented a capsule width of 2.09 $\mathrm{mm}(\mathrm{n}=45)$, length of $14.1 \mathrm{~mm}(\mathrm{n}=45)$, weight of 50.31 $\mathrm{mg}(\mathrm{n}=11)$ and duration of 73 days $(n=4)$. Larvae in the third instar had a cephalic capsule width of $3.05 \mathrm{~mm}(\mathrm{n}=$ 107), length of $19.53 \mathrm{~mm}(\mathrm{n}=92)$, weight of $179.54 \mathrm{mg}(\mathrm{n}=$ 56) and duration of 167 days $(n=4)$ (Table I).

In the laboratory, larvae of Anomonyx developed on the roots of sugarcane sprouts, and penetrated into the tissues causing death of the plant what required substitution during the rearing period. Aragón-García \& Morón (2000) studied Scarabaeidae as pests to sugarcane, collected larvae of $C$. lunulata and $P$. brevidens, and feed them with primary and secondary roots.

From May to July pre-pupae were recorded, and they remained in this stage for 15 days in average $(n=14)$. The pupae occurred from May to August in pupal cells in the soil and the pupal period lasted 28.8 days in average $(n=7)$. Adults emerged May to September (Fig. 6).
Mating of Anomonyx in the laboratory had a mean duration of 24 minutes $(10-45)(n=7)$. After mating, the male remained on top of the female for 15 minutes. This behavior was also observed for L. fuscus (Rodrigues et al. 2008) and C. verticalis (Rodrigues et al. 2010), and it is probably an attempt to avoid the female from mating with other males.

Cyclocephala forsteri. From April to August 2009, 22 third instar larvae were collected and reared in the laboratory. From these only four completed their development and reached the adult stage. From September 2009 to January 2010 no larvae were collected in the field (Fig. 7). Larval population was low in all months, with the highest density in July (1.3 larva $\left.\mathrm{m}^{-2}\right)$.

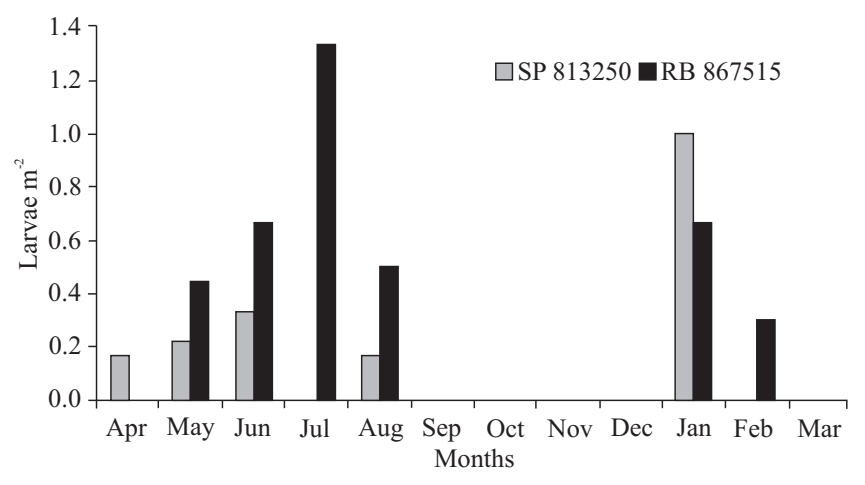

Fig. 7. Mean density of larvae $\mathrm{m}^{-2}$ of Cyclocephala forsteri sampled in two sugarcane varieties, in Sidrolândia, MS, from April 2009 to March 2010.

Pre-pupae occurred from June to September, followed by pupae from September to October. Pre-pupa lasted 65.5 days $(\mathrm{n}=4)$ and the pupal phase lasted 20.5 days $(\mathrm{n}=4)$.

In the laboratory, adults emerged from October to November, presenting an average longevity of 23 days. Females started to lay eggs in November and December. Incubation period lasted 17 days $(n=15)$ in average. The first instar larvae emerged in November and December, and the duration of this instar was 31 days in average. The second instar larvae lasted 53 days and the third 70 days in average (Table I).

In the field, first instar larvae were encountered in January and February of 2010, and those in the third instar again encountered at the end of January to March.

The cephalic capsule of first instar larvae measured 2.5 $\mathrm{mm}$ wide; the second instar $3.8 \mathrm{~mm}$; and the third instar 5.78 $\mathrm{mm}(\mathrm{n}=17)$ with length of $33.23 \mathrm{~mm}(\mathrm{n}=13)$ and weight of $1,378.41 \mathrm{mg}(\mathrm{n}=10)$ (Table I). Similar measures of cephalic capsules were obtained for the first and second instar larvae of C. forsteri by Santos \& Ávila (2007).

Biological and morphological data recorded for C. forsteri in sugarcane are similar to those studied for this species in soybeans, in the region of Dourados, MS, Brazil, by Santos \& Avila (2007).

Cyclocephala verticalis. A total of 120 larvae were collected in the field and reared in the laboratory. From these, 23 pupated and only 16 adults emerged. Larvae of $C$. verticalis 
were collected along the sampling period in the two stands, excepted for July when no larvae were observed. The greatest density (6.6 larvae $\mathrm{m}^{-2}$ ) was in March 2010 (Fig. 8).

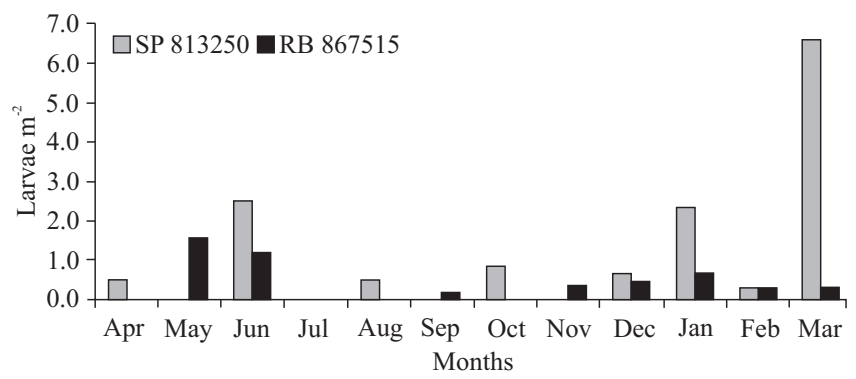

Fig. 8. Mean density of larvae $\mathrm{m}^{-2}$ of Cyclocephala verticalis sampled in two sugarcane varieties, in Sidrolândia, MS, from April 2009 to March 2010 .

Second instar larvae were collected in the field in April and May; the third instar appeared from May to August. The second instar presented $2.66 \mathrm{~mm}(\mathrm{n}=2)$ in the width of cephalic capsule. The third instar presented $4.25 \mathrm{~mm}(\mathrm{n}=8)$ in the width of cephalic capsule, with length of $26.11 \mathrm{~mm}(\mathrm{n}=8)$ and weight of $535.57 \mathrm{mg}(\mathrm{n}=8)$ (Table I). The cephalic capsule was $3.5 \mathrm{~mm}$ wider than those observed by Rodrigues et al. (2010) for this same species fed Brachiaria decumbens.

The pre-pupae of $C$. verticalis reared in the laboratory had a duration of 32.76 days $(n=23)$, and pupa occurred from August to October, with an average duration of 17.38 days $(n=16)$. The adults emerged from August to October, and oviposition started in October. The first instar larvae started to hatch in October. Their cephalic capsule width measured $1.62 \mathrm{~mm}(\mathrm{n}=5)$ in average. In the field the second instar larvae were observed in November and had cephalic capsule width of $2.66 \mathrm{~mm}(\mathrm{n}=5)$. Size cephalic capsule of larvae of the first and second instar are similar to those obtained by Rodrigues et al. (2010) for C. verticalis created in the laboratory, which were 1.5 and $2.5 \mathrm{~mm}$ respectively.

The third instar larvae were observed in December. When these were manipulated, they expelled abundant secretion and moved frentically, probably as a defense mechanism. In laboratory, larvae of $C$. verticalis, not only feed on roots of sugarcane sprouts, but also penetrate the seedpiece of stalk, where they construct a chamber. The seedling usually dies out from the injury caused by the larvae. Oyafuso et al. (2002) verified that third instar larvae of another scarab beetle, Dasylepida sp., also feed on roots and penetrate the seedpiece of sugarcane tunneling it.

In summary, the phytophagous Scarabaeidae recorded in the area of sugarcane in Sidrolândia were L. fuscus, C. verticalis, $C$. forsteri and Anomonyx sp., this last one being the most abundant. The biological cycle of the species of Anomonyx was completed in approximately 349.2 days, characterizing an univoltine insect. The morphological and biological data presented are fundamental for understanding the biology of the whitegrubs attacking the sugarcane crop and for managing this group of soil insects.

\section{ACKNOWLEDGMENTS}

To Juares Fuhrmann, for identification of Anomonyx sp. To Fundação de Apoio ao Desenvolvimento do Ensino, Ciência e Tecnologia do Estado de Mato Grosso do Sul (FUNDECT) for providing the Master's scholarship to the senior author.

\section{REFERENCES}

Aragón-García, A. \& M. A. Morón. 2000. Los coleopteros Melolonthidae asociados a la rizosfera de la cana de azucar em Chietla, Puebla, Mexico. Folia Entomológica Mexicana 108: 79-94.

Arakaki, N.; Y. Sadoyama; M. Kishita; A. Nagayama; A. Oyafuso; M. Ishimine; M. Ota; T. Akino; M. Fukaya; Y. Hirai; K. Yamura \& S. Wakamura. 2004a. Mating behavior of the scarab beetle Dasylepida ishigakiensis (Coleoptera: Scarabaeidae). Applied Journal of Zoology 39: 669-674.

Arakaki, N.; M. Kishita; A. Nagayama; M. Fukaya; H. Yasui; T. Akino; Y. Hirai; S. Wakamura. 2004b. Precopulatory mate guarding by the male green chafer, Anomala albopilosa sakishimana Nomura (Coleoptera: Scarabaeidae). Applied Journal of Zoology 39: 455-462.

Costa, R. B.; P. M. Fernandes; F. S. Oliveira; M. R. Rocha; M. A. Morón \& L. J. Oliveira. 2009. Captura de adultos de Liogenys fuscus (Coleoptera: Melolonthidae) com armadilha luminosa em área sob sistema de plantio direto. Bioscience Journal 25: 1-8.

Gallo, D.; O. Nakano; S. Silveira Neto; R. P. L. Carvalho; G. C. Baptista; E. Berti Filho; J. R. P. Parra; R. A. Zucchi; S. B. Alves; J. D. Vendramim; L. C. Marchini; J. R. S. Lopes \& C. Omoto. 2002. Entomologia Agrícola. Piracicaba. FEALQ, 920 p.

Gordon, R. D. \& D. M. Anderson. 1981. The species of Scarabaeidae (Coleoptera) associated with sugarcane in South Florida. Florida Entomologist 64: 119-131.

Oliveira, L. J.; A. Garcia; C. B. Hoffmann-Campo; J. R. B. Farias; D. R. Sosa-Gomez \& I. C. Corso. 1997. Coró-da-soja Phyllophaga cuyabana. Circular Técnica n. ${ }^{\circ}$ 20, Londrina, EMBRAPA-CNPSo, 30 p.

Oyafuso, A.; N. Arakaki; Y. Sadoyama; M. Kishita; F. Kawamura; M. Ishimine; M. Kinjo \& Y. Hirai. 2002. Life history of the white grub Dasylepida sp. (Coleoptera: Scarabaeidae), a new and severe pest on sugarcane on the Miyako Islands, Okinawa. Applied Journal of Zoology 37: 595-601.

Pardo-Locarno, L. C.; J. Montoya-Lerma; A. C. Bellotti \& A. V. Schoonhovenm. 2005. Structure and composition of the white grub complex (Coleoptera: Scarabaeidae) in agroecological systems of Northern Cauca, Colombia. Florida Entomologist 88: 355-363.

Pereira, P. R. V. S.; K. L. Nechetz; B. A. Halfeld-Vieira \& M. Mourão Júnior. 2004. Ocorrência da broca-da-raiz-do-coqueiro Strategus aloeus (Linnaeus, 1758) (Coleoptera: Scarabaeidae) em coqueirais comerciais no Estado de Roraima. Comunicado Técnico 16. EmbrapaRoraima, $5 \mathrm{p}$.

Rodrigues, S. R.; C. L Barbosa; A. Puker; A. R. Abot \& S. Ide. 2008. Occurrence, biology and behavior of Liogenys fuscus Blanchard (Insecta, Coleoptera, Scarabaeidae) in Aquidauana, Mato Grosso do Sul, Brazil. Revista Brasileira de Entomologia 52: 637-640.

Rodrigues, S. R.; G. A. L, Nogueira; R. R. Echeverria \& V. S. Oliveira. 2010. Aspectos biológicos de Cyclocephala verticalis Burmeister (Coleoptera: Scarabaeidae). Neotropical Entomology 39: 15-18.

Rodrigues, S. R.; J. I. Carmo; V. S. Oliveira; E. F. Tiago \& T. L. Taira. 2011. Ocorrência de larvas de Scarabaeidae fitófagos (Insecta: Coleoptera) em diferentes sistemas de sucessão de culturas. Pesquisa Agropecuária Tropical 41: 87-93. 
Santos, V. \& C. J. Avila. 2007. Aspectos bioecológicos de Cyclocephala forsteri Endrodi, 1963 (Coleoptera: Melolonthidae) no estado do Mato Grosso do Sul. Revista de Agricultura 82: 28-30.

Santos, V. \& C. J. Ávila. 2009. Aspectos biológicos e comportamentais de Liogenys suturalis Blanchard (Coleoptera: Melolonthidae) no Mato Grosso do Sul. Neotropical Entomology 38: 734-740.

Silva, M. T. B. \& E. C. Costa. 1998. Tamanho e número de unidades de amostra de solo para amostragem de larvas de Diloboderus abderus (Sturm) (Coleoptera: Melolonthidae) em plantio direto. Anais da Sociedade Entomológica do Brasil 27: 193-197.

Silva, M. T. B. \& A. E. Loeck. 1996. Ciclo evolutivo e comportamento de Dioboderus abderus Sturm (Coleoptera: Melolonthidae) em condições de plantio direto. Anais da Sociedade Entomológica do Brasil 25: 329-337.

Received 4/8/2010; accepted 3/8/2011

Editor: Sonia Maria Noemberg Lázzari 